\title{
Projected Increase in Fast-Growing and Slow- Dissipating El Niño Events in the 21st Century
}

Hosmay Lopez ( $\nabla$ Hosmay.Lopez@noaa.gov )

NOAA/AOML https://orcid.org/0000-0002-8422-8699

\section{Sang-Ki Lee}

NOAA AOML https://orcid.org/0000-0002-4047-3545

\section{Dongmin Kim}

University of Miami/CIMAS

Andrew Wittenberg

NOAA GFDL https://orcid.org/0000-0003-1680-8963

\section{Sang-Wook Yeh}

Hanyang University

\section{Article}

Keywords: El Niño, ocean science, Southern Oscillation (ENSO)

Posted Date: January 22nd, 2021

DOI: https://doi.org/10.21203/rs.3.rs-146174/v1

License: (c) (1) This work is licensed under a Creative Commons Attribution 4.0 International License. Read Full License 


\title{
Projected Increase in Fast-Growing and Slow-Dissipating EI Niño Events in
}

\section{the 21st Century}

${ }^{*}$ Hosmay Lopez ${ }^{1}$, Sang-Ki Lee ${ }^{1}$, Dongmin Kim²,1, Andrew T. Wittenberg ${ }^{3}$, and Sang-Wook Yeh ${ }^{4}$

${ }^{1}$ Atlantic Oceanographic and Meteorological Laboratory, NOAA, Miami, FL

${ }^{2}$ Cooperative Institute for Marine and Atmospheric Studies, University of Miami, Miami, FL

${ }^{3}$ Geophysical Fluid Dynamics Laboratory, NOAA, Princeton, NJ

${ }^{4}$ Department of Marine Science and Convergent Technology, Hanyang University, Ansan, Korea

\begin{abstract}
Future changes in the seasonal evolution of El Niño - Southern Oscillation (ENSO) during the onset and decay phases have received little attention by the research community. This work investigates the projected changes in the spatio-temporal evolution of El Niño events in the $21^{\text {st }}$ Century (21C) using a large ensemble simulation of a couple general circulation model under anthropogenic forcing. Here we show that El Niño is projected to (1) initiate sooner in boreal spring, (2) to grow at a faster rate, (3) to persist longer over the eastern and far eastern Pacific, and (4) to have a broader impact on remote teleconnections. Significant changes in the tropical Pacific mean state, dominant feedback processes, and a projected increase in stochastic westerly wind burst forcing largely explain the fast growing and slow dissipating El Niño in the late 21C. Important implications of these findings are that the global climate impacts are projected to become more significant and persistent, owing to the extended persistence of El Niño.
\end{abstract}

Corresponding author address: Dr. Hosmay Lopez, NOAA, Atlantic Oceanographic and Meteorological Laboratory, 4301 Rickenbacker Causeway, Miami, FL 33149, USA. E-mail: Hosmay.lopez@noaa.gov 


\section{Introduction}

El Niño - Southern Oscillation (ENSO) is the dominant mode of interannual oceanatmospheric variability in the tropical Pacific. Through its atmospheric teleconnections, ENSO is also the major source of seasonal predictability of global climate and extreme events ${ }^{1,2,3}$. Previous studies based on the climate models participating in the Coupled Model Intercomparison Project Phase 5 (CMIP5) have suggested an increase in the frequency and amplitude of El Niño and associated precipitation anomalies in the $21^{\text {st }}$ Century (21C) in response to increasing greenhouse gases ${ }^{4,5,6,7,8,9}$. Several studies have attributed these shifts in El Niño frequency and amplitude to the projected changes in the tropical Pacific mean state. Specifically, consistent with the projected weakening of the Walker Circulation, the equatorial Pacific upwelling weakens, thus producing an El Niño-like warming pattern ${ }^{10,11}$. This El Niñolike warming reduces the near-equatorial zonal and meridional sea surface temperature (SST) gradients, facilitating shifts in convection to the eastern equatorial Pacific, and increasing the occurrence of extreme El Niño events ${ }^{6,12}$. In addition, the reduced upwelling and associated increase in vertical temperature gradients enhance convective feedbacks and atmosphere-ocean coupling, leading to an increased frequency and amplitude of El Niño ${ }^{8,13}$. While most of these projected signals have yet to emerge clearly in instrumental observations ${ }^{14,15}$, paleo proxy evidence does suggest that ENSO has significantly strengthened in recent decades relative to prior centuries $^{16,17}$.

However, most previous studies have focused on future changes of ENSO during the peak phase in boreal winter, or on changes in the diverse spatial patterns of ENSO SST anomalies ${ }^{18,19}$. In contrast, future changes in the seasonal evolution of ENSO during the onset and decay phases

have received little attention ${ }^{20}$. The onset and decay phases of ENSO, which typically occur in 
boreal spring and summer, have direct impacts on climate variability and extreme events around the globe, such as the Southeast Asian monsoon ${ }^{21}$, tropical cyclones ${ }^{22,23,24}$, and tornado outbreaks in the United States ${ }^{25}$. Therefore, there is an urgent need to better understand not only the spatial changes but also the temporal changes in ENSO characteristics under the influence of increasing greenhouse gases (GHGs), and their impacts on climate variability and predictability. This study analyzes the Community Earth System Model - Large Ensemble (CESM-LENS, see Methods section) under present conditions and future climate projections to better understand future changes in ENSO characteristics, focusing on the onset and decay phases.

\section{Faster Growth and Slower Decay of EI Niño Events in the $21^{\text {st }}$ Century}

Similar to most of the CMIP5 models, the CESM-LENS response to increasing GHGs is an El Niño-like warming pattern in the tropical Pacific, reduced Walker circulation, stronger convective feedback in the eastern equatorial Pacific, and thus an increase in the frequency and amplitude of El Niño ${ }^{26}$. In total, we found $350 \mathrm{El}$ Niño events in the 30 ensemble members for the late $20^{\text {th }}$ century (i.e., $1951-2000$ or $20 \mathrm{C}$ hereafter), and 419 events for the late $21^{\text {st }}$ century (i.e., 2051-2100 or 21C hereafter). This indicates a $20 \%$ increase in the frequency of El Niño, consistent with earlier studies based on CMIP5 models ${ }^{6}$. This increase is significant when compared to the expected natural variability (supplementary Fig. S1), and suggests that anthropogenic influence on El Niño occurrence will emerge from natural variability by the middle of the $21 \mathrm{C}$ under the RCP8.5 scenario.

Figures 1a, b, c, and d show time-longitude plots of the composite mean tropical Pacific El Niño SST anomalies (SSTAs) for the observed, CESM-LES 20C (i.e., the latter part of 20C, 1951-2000 period), the CESM-LES 21C (i.e., the latter part of 2051-2100 period), and the difference (21C minus 20C), respectively. The bottom row of Fig. 1 is similar to the top row, but 
showing the composite mean precipitation anomalies. Compared to observations, the CESM has stronger and westward-displaced El Niño events (Fig. 1a,b), and more westward propagation of the SSTAs. These model biases are common among many CMIP5 models ${ }^{27,28}$ While the SSTA biases are somewhat subtle, the precipitation anomaly biases are significant, especially in boreal summer of year 0 (Fig. 1e,f). Most of these differences in interannual variability can be traced back to biases in the mean state (Fig. S2), such as the overly-intense and westward-displaced equatorial cold tongue, the double intertropical convergence zone (ITCZ), and the warm SST bias in the far eastern equatorial Pacific ${ }^{29}$.

The projected changes in El Niño SSTAs between 20C and 21C (Fig. 1d) clearly show that El Niño develops much faster east of the dateline, nearly reaching the local peak SSTAs as early as mid-August. Warm El Niño SSTAs in the far eastern Pacific persist throughout boreal spring in $21 \mathrm{C}$, extending the El Niño peak by about 2 to 3 months relative to $20 \mathrm{C}$. Therefore, El Niño develops more rapidly, reaches a larger amplitude, and persists longer in $21 \mathrm{C}$. However, warm El Niño SSTAs in the central Pacific (west of the date line) dissipate more rapidly during boreal winter and spring. These projected changes mark a contrast in El Niño SSTA evolution from a westward progression in $20 \mathrm{C}$ to an eastward progression in $21 \mathrm{C}$.

The 20C El Niño composite resembles the 2015-16 El Niño event, which had relatively weak climate impacts on North America, while the 21C composite looks more like the 1982-83 and 1997-98 events which had stronger climate impacts ${ }^{30}$. Consistent with these SSTA changes, the precipitation anomalies are also enhanced during 21C, indicating enhanced air-sea coupling, an eastward shift in atmospheric convection, and a potential larger remote influence.

\section{What Drives the Projected Changes in El Niño During the Onset and Decay Phases? \\ a) Mixed Layer Heat Budget Analysis}


The seasonal El Niño evolution is analyzed using a mixed layer heat budget, which includes the dominant feedback mechanisms for ENSO growth. Figure 2 depicts the composite evolutions of heat storage, three feedback terms (i.e., thermocline, zonal advective, and Ekman feedbacks), and a residual term in the same order as they appear in Eq. 1 (see Methods). Note that the largest differences between $20 \mathrm{C}$ and $21 \mathrm{C}$ are in the amplitude rather than spatiotemporal structure. Specifically, it is clear that the thermocline, zonal advective, and Ekman feedbacks are greatly enhanced (points labeled A in Fig. 2) in the central equatorial Pacific during the developing phase in boreal summer and fall (Year 0), readily explaining the faster rise in heat content (Fig. 2 green contour) and the faster growth of SSTAs during the growth phase (Fig. 1d). During the late decay phases in April-July (Year +1$)$, the Ekman feedback is enhanced in the central and eastern equatorial Pacific between $150^{\circ} \mathrm{W}$ and $100^{\circ} \mathrm{W}$ (point labeled B in Fig. 2). A similar increase in the Ekman feedback is also found during the peak phase in boreal winter. Interestingly, the thermocline feedback is reduced in the central equatorial Pacific between $170^{\circ} \mathrm{E}$ and $140^{\circ} \mathrm{W}$ during the decay phase in boreal spring (point labeled $\mathrm{C}$ in Fig. 2). Overall, the residual term mostly constitutes a damping of the heat content anomaly.

To further investigate what dynamical processes are responsible for the projected changes in feedbacks and thus El Niño growth, we repeat the computations of the feedback terms in Eq. 1 (Methods) by either fixing the mean state (i.e., overbar) or the anomalies (i.e., primes) to that of the $20^{\text {th }}$ Century (see supporting information and Figs. S3 and S4 therein). The projected changes in the thermocline feedback are mostly explained by an increase in the vertical gradient of anomalous temperature $\left(\frac{\partial T \prime}{\partial z}\right.$ in Fig. S3 and Fig. S4d) rather than the projected reduction in mean upwelling ( $\bar{w}$ in Fig. S3 and Fig. S4g). In contrast, the zonal advective feedback changes are dominated by an increase in the anomalous zonal current ( $u^{\prime}$, Fig. S3 and Fig. S4e) rather than 
changes in the mean zonal temperature gradient $\left(\frac{\partial \bar{T}}{\partial x}\right.$, Fig. S3 and Fig. S4h). Whereas, the projected increase of the Ekman feedback can be explained by both contributions from anomalous upwelling ( $w^{\prime}$, Fig. S3 and Fig. S4f) and an increase in the mean stratification $\left(\frac{\partial \bar{T}}{\partial z}\right.$, Fig. S3 and Fig. S4i): the stronger future $\frac{\partial \bar{T}}{\partial z}$ supports growth during Year 0, while the stronger future $w^{\prime}$ helps to maintain the far eastern Pacific SSTA into the boreal spring of Year +1 .

Projected changes of major El Niño feedbacks (e.g., increased positive thermocline feedback east of $140^{\circ} \mathrm{W}$ and negative thermocline feedback west of $140^{\circ} \mathrm{W}$, and increased positive Ekman feedback between $150^{\circ} \mathrm{W}$ and $100^{\circ} \mathrm{W}$ ) cause El Niño SSTAs to propagate eastward during the decay phase in the late $21 \mathrm{C}$, opposite to the westward propagation of SSTAs typically observed during the late 20C (Figs. 1b and c). Analysis of future projections of ENSO SSTAs in the CMIP5 models has shown an increase in eastward SSTA propagation during the decay phase of El Niño ${ }^{31}$. Zonal SSTA propagation during the termination of El Niño is determined by the balance among the thermocline feedback, zonal advective and Ekman feedbacks ${ }^{32}$. The thermocline feedback tends to drag SSTAs eastward, while the zonal advective and Ekman feedbacks tend to drag SSTAs westward, as evident in Fig. 1 and 2 here.

It is important to investigate what mechanism could explain the tendency to have a shift towards stronger eastern Pacific El Niño events in the late 21C (Fig. 1). The delayed thermocline feedback is one of the major transitioners of strong El Niño events ${ }^{33}$. For example, the negative thermocline feedback is enhanced in the central Pacific west of $140^{\circ} \mathrm{W}$ during the decay phase (Fig. 2). Analysis of the projected changes of each component of the thermocline feedback suggests that while the mean upwelling is weakened due to weaker trade winds, $\frac{\partial T^{\prime}}{\partial z}$ is projected to increase (Figs. S3 and S4). These changes are potentially due to either (1) larger thermocline 
depth anomalies associated with stronger wind anomalies in the future (Fig. S5) and/or (2) a stronger dependence of $\frac{\partial T \prime}{\partial z}$ on thermocline depth anomalies. Here we found that the mean thermocline is projected to deepens (shoals) in the eastern (western) Pacific and sharpen (e.g., increased $\frac{\partial \bar{T}}{\partial z}$ ) during the $21 \mathrm{C}$ (Fig. S6), strengthening the thermocline feedback.

In summary, the projected changes in feedback terms during El Niño developing and decay phases, as shown in Fig. 2, readily explain why El Niño events in the late 21C develop sooner (i.e., grow at a faster rate) and persist longer (i.e., dissipate at a slower rate) in the eastern and far eastern Pacific, but decay earlier in the central Pacific. In the next sections, we further explore the effects of Pacific mean-state changes and wind anomalies on the spatio-temporal El Niño evolution.

\section{b) Impact of a changing tropical Pacific climatology}

Figure 3 shows longitude-time plots of the equatorial Pacific mean states for a) SST, b) thermocline depth (defined by the depth of the $20^{\circ} \mathrm{C}$ isotherm), and c) precipitation, during 1951 2000 and their projected $21 \mathrm{C}$ changes d), e), and f) respectively. The projected increase in equatorial Pacific time-mean SST is strongest over the cold-tongue region in boreal fall and winter, the seasons when a climatologically shallow thermocline and strong cold tongue tend to intensify the vertical and zonal temperature gradients in the equatorial central Pacific. This seasonal intensification is weakened in $21 \mathrm{C}$, leading to weaker vertical and zonal temperature gradients during boreal fall and winter. Additionally, the time-mean thermocline flattens along the equator, shoaling the thermocline in the west and deepening it in the east (Fig. 3e). The thermocline also shows more intense thermal stratification (Fig. S6), particularly during May- 
October in the central equatorial Pacific. The time-mean precipitation is also projected to increase over the central Pacific, especially during May-October (Fig. 3f).

These future changes in the time-mean precipitation and thermocline in the central Pacific $\left(160^{\circ} \mathrm{E}-120^{\circ} \mathrm{W}\right)$ during boreal summer provide a more favorable background environment to support faster and stronger development of El Niño, by enhancing the thermocline feedback. In the far eastern equatorial Pacific $\left(100^{\circ} \mathrm{W}-80^{\circ} \mathrm{W}\right)$ in boreal spring and early summer, the future climatology shows a deeper thermocline and more precipitation (Figures $3 \mathrm{e}$ and $\mathrm{f}$ ). These changes suggest that the far eastern equatorial Pacific in boreal spring provides more favorable background environmental conditions for active air-sea interactions and convective activity in 21C, as evidenced by the projected enhancement of convective precipitation during $21 \mathrm{C}$ El Niño events (Fig. 1), thus supporting the persistent El Niño SSTAs in the far eastern Pacific during the decay phase in boreal spring (Fig.1d).

\section{c) Changes in Westerly Wind Bursts}

Previous studies have stressed the role of stochastic forcing in modulating ENSO growth, variability, and predictability. For instance, the stochastic optimal forcing pattern, the noise forcing pattern prone to lead to ENSO growth, is consistent with the spatial structure associated with observed Westerly Wind Bursts (WWBs) $)^{34,35}$. WWBs excite downwelling Kelvin waves that propagate eastward along the equator ${ }^{36,37,38}$. WWBs represent a fundamental process for the waveguide during the onset of El Niño, and help generate warm SSTAs in the central and eastern equatorial Pacific during El Niño ${ }^{39}$. The characteristics of ENSO events are also strongly affected by WWBs $\mathrm{W}^{40,41,42,43,44}$. For instance, WWBs more strongly modulate the thermocline feedback than the zonal advective feedback, with important implications for El Niño diversity ${ }^{45}$. Therefore, if there is an enhanced SST-zonal wind stress coupling under anthropogenic forcing, 
it should manifest as an increase in the frequency and/or intensity of WWBs. CCSM4, the previous version of the model used here, captures the main characteristics of WWBs including their longitude distributions, durations, zonal extensions, and variability at intraseasonal, seasonal, and interannual time scales ${ }^{46}$.

The WWB forcing and induced equatorial Kelvin wave response were computed using daily zonal wind stress $\left(\tau_{x}\right)$ from the $20 \mathrm{C}$ and $21 \mathrm{C}$ simulations of the CESM-LENS (see Methods and Fig. $3 g$ and h). Note that there is a significant increase in downwelling Kelvin wave forcing for the $21 \mathrm{C}$ compared to the $20 \mathrm{C}$, suggesting an increase in WWB activity, enhanced SST- $\tau_{x}$ coupling, and thus El Niño forcing. There is also a significant shift of this forcing to earlier in the year (Fig. 3h), from late April (20C) to late March (21C). This result is also consistent with the projected earlier and faster onset of El Niño (Fig. 1) and also with the projected increase in the thermocline feedback during the onset phase (Fig. 2). Enhanced WWB activity during boreal spring, and enhanced air-sea coupling in the far eastern Pacific, explain the early onset and slower decay of El Niño in the 21C. However, WWBs are believed to be state-dependent, thus a question remains whether the projected increase in WWBs in the spring and summer is a direct result of the projected increase in the background SST and precipitation (Fig. 3a-f). Previous studies have shown that the ITCZ position strongly influences the nonlinearity of the equatorial zonal wind response to SSTAs, which derives largely from WWBs state dependence ${ }^{47,48}$. Such nonlinearity, in turn, strongly modifies ENSO phase asymmetries of event amplitude, duration, and transition, which are strongly linked to the El Niño spatiotemporal evolution discussed here. This is a topic of future study.

\section{Remote Impacts}


El Niño-related anomalous precipitation and upper-level divergence modulate the extratropical circulation via atmospheric westward Rossby wave propagation ${ }^{49,50}$. During El Niño events, the subtropical Pacific jet stream shifts southward along the western coast of the United States, influencing weather and climate over North America ${ }^{51,52,53}$. The enhanced precipitation over the southern and western US during El Niño can be explained by eddy-forced ascent and tropospheric cooling in midlatitudes ${ }^{52}$. The teleconnection patterns and predictability depend on the spatial details of the ENSO SSTAs in the tropical Pacific. Compared to eastern Pacific El Niño, Central Pacific El Niño produces a more robust southward shift of the subtropical jet stream ${ }^{54}$. Yet model forecasts of $2 \mathrm{~m}$ temperature and precipitation over North America are more skillful for eastern Pacific El Niños than central Pacific El Niños ${ }^{55}$.

Motivated by these findings and the demonstrated projected changes in the spatio-temporal evolution of El Niño events and associated convection (Fig. 1), we investigate how remote effects of El Niño events will change in the future - owing to changes in both the spatial patterns and the temporal character of the tropical Pacific climate anomalies. Figure 4 depicts the global 20C El Niño composite, and the projected future changes (21C minus 20C) in composite circulation, surface air temperature, and precipitation during December-January-February (DJF) of the peak phase of El Niño event. Fig. 4a shows the classical teleconnection patterns associated with El Niño SSTA forcing, as measured by the $200 \mathrm{hPa}$ streamfunction (contour) and velocity potential (color) for the 20C, and its influence on surface temperature and precipitation. Similarly, Fig. $4 \mathrm{~b}$ shows the impact of the $21 \mathrm{C}$ minus $20 \mathrm{C}$ projected changes.

Note that the tropical Pacific atmospheric forcing is projected to increase and shift eastward in the $21 \mathrm{C}$ (Fig. $4 \mathrm{~b}$ color), leading to an eastward intensification of the circulation anomaly. Consequently, there is an enhanced response in temperature and precipitation, mostly over the 
southern and southwestern U.S. The enhanced cooling is a result of increased clouds and precipitation over the southern U.S, with changes in the teleconnections being generally consistent among climate models ${ }^{56}$. The projected enhancement of the $20 \mathrm{C}$ teleconnection into the $21 \mathrm{C}$ is consistent with previous work, which showed that sufficiently warm and persistent SSTA in the far eastern equatorial Pacific is required to excite teleconnection patterns that influence rainfall over the western U.S ${ }^{30}$. Over South America, El Niño's remote effects are also projected to increase, with enhanced warming over the northern two thirds of the continent and drier Amazon basin. Over Australia, there is a projected increase in the El Niño warming continent-wide, as well as more drying of the northwestern region associated with enhanced upper-level convergence and anticyclonic circulation (Fig. 4b).

It is also worth examining the projected changes during the onset and decay phases of El Niño, when significant changes in SSTAs and precipitation are projected to occur (Fig. 1). Future changes in El Niño's remote impacts during the onset phase (June-July-August in Year 0) are mostly over the Southern Hemisphere (Fig. S7). This is consistent with enhanced SSTAs and precipitation over the tropical Pacific (Fig. 1), the associated upper tropospheric teleconnection response, and the notion that the Southern Hemisphere ENSO response leads the ENSO peak in the tropics. During the decay phase (e.g., January-February-March in Year 1, Fig. S8), El Niño's remote effects mimic those of the peak phase, with enhanced future teleconnections to the surface temperature and precipitation responses over Australia and North and South America, again consistent with enhanced tropical Pacific SSTAs and convection.

\section{Concluding Remarks}

The main objective of this work is to better understand the dominant drivers that modulate the projected changes in the spatio-temporal evolution of El Niño events during the $21 \mathrm{C}$. Our 
major findings, based on CESM model projections, are that El Niño in the late $21 \mathrm{C}$ is projected to (1) initiate sooner in boreal spring, (2) grow at a faster rate, and (3) persist longer over the eastern and far eastern Pacific. The projected increase in the equatorial Pacific mean-state rainfall in boreal spring and summer, shallower thermocline in the central Pacific, deeper thermocline in the far eastern Pacific in spring, and associated changes in dominant feedback processes (i.e., thermocline, zonal advective and Ekman feedbacks) largely explain the fastergrowing and slower-dissipating El Niño in the late 21C. We also found a significant projected increase in the stochastic noise forcing in the form of WWBs, and also a significant shift of the WWB forcing to occur earlier in the year in the late 21C. These changes in WWB forcing are consistent with the projected earlier and faster onset of El Niño (Fig. 1), the projected increase in the thermocline feedback during the developing phase, and the pronounced shift toward more eastward propagation of El Niño SSTAs in the 21C compared to the 20C.

Compared to the late 20C, the frequency of El Niño in the late $21 \mathrm{C}$ increases by about $20 \%$ which is well outside the internal variability of the CESM. Further statistical analysis shows that there is a $47 \%$ increase in the number of El Niño events that persist into the subsequent boreal spring in the far eastern equatorial Pacific (not shown). This persistent El Niño variety is responsible for the largest climate impacts on North America ${ }^{30}$. Therefore, and as shown here, the extratropical teleconnections and their climate impacts will most likely become more significant and persistent, owing to the extended persistence of the SSTAs in the eastern Pacific. Another important implication is that the lead time for skillful seasonal El Niño forecasts may be reduced in the future, due the faster development of El Niño and a larger role for stochastic WWBs.

Simulations of ENSO have improved substantially over the past decade, but there remain 
common model biases that add caveats to the results presented here. These biases include ITCZs in wrong place, an overly-intense cold tongue, insufficient stirring by tropical instability waves, unresolved convective momentum transport in the atmospheric boundary layer, cloud-radiative feedbacks, difficulties representing near-surface ocean mixing, representing sub-grid scale processes, which may affect model projections of future ENSO behavior ${ }^{27,31,57,58,59,60,61,62,63,64}$. Further studies, using a diverse set of models and emergent constraints, will be needed to assess the robustness of the results reported here.

\section{Methods}

\section{Observations and Model Data}

The results presented here rely on observations and model simulations. For observations, we analyze the NOAA Extended Reconstructed Sea Surface Temperature version $5^{65}$ (ERSST.v5) and the rainfall from the Global Precipitation Climatology Project ${ }^{66}$ (GPCP version 2.3). The model simulations are taken from a 30-member ensemble simulation of the Community Earth System Model - Large Ensemble Simulation ${ }^{67}$ (CESM-LENS). This Earth system model consists of atmosphere, land, ocean, glacier, and sea ice components, all linked by a flux coupler. The atmospheric component has 30 vertical levels with a horizontal resolution of $1.25^{\circ}$ longitude by $0.94^{\circ}$ latitude. The ocean model component has a $1^{\circ}$ horizontal resolution with 60 vertical levels. CESM is one of the most skillful models in representing ENSO variability and associated global teleconnections ${ }^{6,56}$. The analysis for the historical period (i.e., 20C) comprises 30 ensemble members during 1951-2005 under historical radiative forcing. The 21C projection also comprises 30 ensemble members during 2006-2100 under the Representative Concentration Pathway 8.5

radiative forcing of the CMIP5 design protocol $^{68,69}$. Each ensemble member has a distinct 
climate trajectory due to differences in the atmospheric initial conditions. Thus, differences among ensemble members are solely due to internal variability.

\section{El Niño event definition}

In this study, we define an El Niño event following the method used at the NOAA Climate Prediction Center (i.e., 3-month averaged SSTAs over the Niño3.4 region (e.g., area average from $170^{\circ} \mathrm{W}-120^{\circ} \mathrm{W}$ and $5^{\circ} \mathrm{S}$ to $5^{\circ} \mathrm{N}$ ) should exceed $0.5^{\circ} \mathrm{C}$ for a minimum of five consecutive seasons), where SSTAs are defined by removing the ensemble mean SST and monthly climatology for each ensemble member. The monthly climatology is defined for the period of 1951-2000 for the observations and CESM-LENS 20C and from 2051-2100 for the CESMLENS 21C. Thus, SSTAs for a given ensemble member objectively exclude any trend associated with the increasing GHGs as well as responses of low-latitude volcanic eruptions ${ }^{70,71}$ such as Pinatubo in 1991-92.

\section{Mixed Layer Heat Budget}

The mixed layer temperature tendency is driven by the thermocline, zonal advective, and Ekman feedbacks as described by the right-hand-side integrands in Eq. 1, plus a residual term. Here, $T$ denotes the mixed layer temperature, and $u$ and $w$ are the zonal and vertical components of velocity, respectively, which are evaluated in an Eulerian reference frame on the model grid. $H=75 m$ is the mixed layer depth, taken here to be constant throughout the tropical Pacific ${ }^{10}$. Note that we repeated the analysis using different mixed layer depths, ranging from $H=30 \mathrm{~m}$ to $100 \mathrm{~m}$ and the results were consistent. The entrainment velocity is taken to be the vertical velocity at the base of the mixed layer. Bars and primes represent the climatological mean and monthly anomalies, respectively, computed independently for the $20 \mathrm{C}$ and $21 \mathrm{C}$. The residual term serves mostly to damp the heat content anomaly and is composed of the surface net heat fluxes, 
meridional heat advection, diffusive heating, unresolved sub-grid scale heat fluxes, sub-monthly scale heating, and also the zonal and meridional advection terms not listed in Eq. 1 (i.e., $\bar{u} \frac{\partial T^{\prime}}{\partial x}$; $\left.u^{\prime} \frac{\partial T^{\prime}}{\partial x} ; w^{\prime} \frac{\partial T^{\prime}}{\partial z}\right)^{65,66}$

$$
\int_{-H}^{0} \frac{\partial T^{\prime}}{\partial t} d z=-\int_{-H}^{0}\left[\bar{w} \frac{\partial T^{\prime}}{\partial z}+u^{\prime} \frac{\partial \bar{T}}{\partial x}+w^{\prime} \frac{\partial \bar{T}}{\partial z}\right] d z+\text { Residual }
$$

\section{Wind-forced equatorial oceanic Kelvin waves}

To identify WWBs, we first remove the 91-day running-mean climatology from the daily zonal wind stress. Then, the anomalous wind stress is averaged between $2.5^{\circ} \mathrm{S}$ and $2.5^{\circ} \mathrm{N}$. Westerly wind stress anomalies exceeding $+0.03 \mathrm{Nm}^{-2}$, with a minimum zonal fetch of $500 \mathrm{~km}$, and a minimum duration of 3 days are defined as WWBs ${ }^{72,73}$. Since the influence of WWBs on equatorial dynamics depends on the amplitude, fetch, duration, and probability of occurrence of the forcing, a single parameter is defined here which encompasses all those aspects into one index. This index is summarized by Eq. 2 and is referred to as the downwelling Kelvin wave forcing, and thus is directly linked to El Niño evolution ${ }^{74}$. Eq. 2 considers the amplitude, zonal fetch, and temporal duration of the WWBs, summarizing their integrated impact on ENSO. Here, $\operatorname{WWB}(x, t)$ represents the wind stress anomaly associated with WWBs, which is a function of longitude $x$, which is centered at $x_{o}$, and time $t$. Note that the Kelvin wave forcing is the integral of the WWB forcing from the central longitude $x_{o}$ to the eastern boundary $x_{e}$ along the characteristics (i.e., $\frac{x-x_{0}}{c}$ ) of equatorially trapped Kelvin waves with the observed $c=2.4 \mathrm{~ms}^{-1}$ phase speed ${ }^{74}$. For the purpose of this work, variations in the parameter $c$ are not critical as we are not attempting to investigate the timing of forcing versus response, only the changes in the statistics of the forcing under anthropogenic influences. 


$$
\text { Kelvin Wave Forcing }=\int_{x_{0}}^{x_{e}} \operatorname{WWBs}\left(x, \frac{x-x_{0}}{c}\right) d x
$$

\section{Acknowledgements}

We would like to acknowledge Dr. Renellys Perez (NOAA/AOML) and Dr. Elizabeth Johns (NOAA/AOML) for their comments and suggestions that greatly improved the manuscript. This research was carried out in part under the auspices of the Cooperative Institute for Marine and Atmospheric Studies, a cooperative institute of the University of Miami and the National Oceanic and Atmospheric Administration (NOAA), cooperative agreement NA 20OAR4320472 . Hosmay Lopez acknowledges support from NOAA/CPO/MAPP Award NA19OAR4310282.

Contributions: H.L. conceived the study and wrote the initial draft of the paper. H.L., S.K.L., D.K., A.T.W., and S.W.Y. contributed to the design, the statistical analysis, and interpretation of the results as well as the writing of the final version of the paper.

Competing financial interests: The authors declare no competing financial interests.

\section{References}

1. Jin F-F (1997) An equatorial ocean recharge paradigm for ENSO. Part I: conceptual model. J Atmos Sci 54:811-829.

2. McPhaden MJ, Zebiak SE, Glantz MH (2006) ENSO as an integrating concept in earth science. Science 314:1740-1745.

3. Yu, J. Y., Zou, Y., Kim, S. T., \& Lee, T. (2012). The changing impact of El Niño on US winter temperatures. Geophysical Research Letters, 39(15).

4. Power, S., F. Delage, C. Chung, G. Kociuba, and K. Keay, 2013: Robust twenty-first-century projections of El Niño and related precipitation variability. Nature, 502, 541-545, 
doi:10.1038/nature12580.

5. Xu, K., Tam, C. Y., Zhu, C., Liu, B., \& Wang, W. (2017). CMIP5 projections of two types of El Niño and their related tropical precipitation in the twenty-first century. Journal of Climate, 30(3), 849-864.

6. Cai W., Borlace S, Lengaigne M, Rensch P, Collins M, Vecchi G, Timmermann A, Santoso A, McPhaden M, Wu L, England M, Wang G-J, Guilyardi E, Jin F-F (2014). Increasing frequency of extreme El Niño events due to greenhouse warming. Nat Clim Change 4:111116

7. Cai, W., Santoso, A., Wang, G., Yeh, S.W., An, S.I., Cobb, K.M., Collins, M., Guilyardi, E., Jin, F.F., Kug, J.S. and Lengaigne, M. (2015). ENSO and greenhouse warming. Nature Climate Change, 5(9), pp.849-859.

8. Wang, B., Luo, X., Yang, Y. M., Sun, W., Cane, M. A., Cai, W., Yeh, S.-W. \& Liu, J. (2019). Historical change of El Niño properties sheds light on future changes of extreme El Niño. Proceedings of the National Academy of Sciences, 116(45), 22512-22517.

9. Carréric, A., Dewitte, B., Cai, W., Capotondi, A., Takahashi, K., Yeh, S. W., ... \& Guémas, V. (2020). Change in strong Eastern Pacific El Niño events dynamics in the warming climate. Climate Dynamics, 54(1-2), 901-918.

10. DiNezio, P. N., A. C. Clement, G. A. Vecchi, B. J. Soden, B. P. Kirtman, and S.-K. Lee, 2009: Climate response of the equatorial Pacific to global warming. J. Climate, 22, 48734892, doi:10.1175/2009JCLI2982.1.

11. Collins, M., and Coauthors, 2010: The impact of global warming on the tropical Pacific Ocean and El Niño. Nat. Geosci., 3, 391- 397, doi:10.1038/ngeo868. 
12. Watanabe, M., J.-S. Kug, F.-F. Jin, M. Collins, M. Ohba, and A. T. Wittenberg, 2012: Uncertainty in the ENSO amplitude change from the past to the future. Geophys. Res. Lett., 39, L20703. doi:10.1029/2012GL053305

13. Cai, W., Wang, G., Dewitte, B. et al. Increased variability of eastern Pacific El Niño under greenhouse warming. Nature 564, 201-206 (2018). https://doi.org/10.1038/s41586-018$\underline{0776-9}$

14. L'Heureux, M. L., K. Takahashi, A. B. Watkins, A. G. Barnston, E. J. Becker, T. E. Di Liberto, F. Gamble, J. Gottschalck, M. S. Halpert, B. Huang, K. Mosquera-Vásquez, and A. T. Wittenberg, 2017: Observing and predicting the 2015/16 El Niño. Bull. Amer. Meteor. Soc., 98 (7), 1363-1382. doi:10.1175/BAMS-D-16-0009.1

15. Newman, M., A. T. Wittenberg, L. Cheng, G. P. Compo, and C. A. Smith, 2018: The extreme 2015/16 El Niño, in the context of historical climate variability and change. Section 4 of: "Explaining extreme events of 2016 from a climate perspective." Bull. Amer. Meteor. Soc., 99 (1), S16-S20. doi:10.1175/BAMS-D-17-0116.1

16. McGregor, S., A. Timmermann, M. H. England, O. Elison Timm, and A. T. Wittenberg, 2013: Inferred changes in El Niño-Southern Oscillation variance over the past six centuries. Clim. Past, 9, 2269-2284. doi:10.5194/cp-9-2269-2013

17. Grothe, P. R., Cobb, K. M., Liguori, G., Di Lorenzo, E., Capotondi, A., Lu, Y., et al. ( 2020). Enhanced El Niño-Southern oscillation variability in recent decades. Geophysical Research Letters, 47, e2019GL083906. doi:10.1029/2019GL083906

18. Capotondi, A., Wittenberg, A. T., Newman, M., di Lorenzo, E., Yu, J. Y., Braconnot, P., ... Yeh, S. W. (2015b). Understanding ENSO diversity. Bulletin of the American Meteorological Society, 96(6), 921-938. https://doi.org/10.1175/BAMS-D-13-00117.1 
19. Capotondi, A., A. T. Wittenberg, J.-S. Kug, K. Takahashi, and M. McPhaden, 2020: ENSO diversity. Chapter 4 of: El Niño Southern Oscillation in a Changing Climate, American Geophysical Union, Washington, DC, pp. 65-86. doi: 10.1002/9781119548164.ch4

20. Yun, K.-S., Yeh, S.-W., \& Ha, K.-J. (2016). Inter-El Niño variability in CMIP5 models: Model deficiencies and future changes. Journal of Geophysical Research: Atmospheres, 121, 3894-3906. https://doi.org/10.1002/2016JD024964

21. Zhang, Wenjun, F.-F. Jin, M. F. Stuecker, A. T. Wittenberg, A. Timmermann, H.-L. Ren, J.S. Kug, W. Cai, and M. Cane, 2016: Unraveling El Niño's impact on the East Asian monsoon and Yangtze River summer flooding. Geophys. Res. Lett., 43 (21), 11375-11382. doi:10.1002/2016GL071190

22. Zhang, Wei, G. A. Vecchi, H. Murakami, T. Delworth, A. T. Wittenberg, A. Rosati, S. Underwood, W. Anderson, L. Harris, R. Gudgel, S.-J. Lin, G. Villarini, and J.-H. Chen, 2016: Improved simulation of tropical cyclone responses to ENSO in the western north Pacific in the high-resolution GFDL HiFLOR coupled climate model. J. Climate, 29, 13911415. doi:10.1175/JCLI-D-15-0475.1

23. Vecchi, G. A., T. Delworth, R. Gudgel, S. Kapnick, A. Rosati, A. T. Wittenberg, F. Zeng, et al., 2014: On the seasonal forecasting of regional tropical cyclone activity. J. Climate, 27, 7994-8016. doi:10.1175/JCLI-D-14-00158.1

24. Krishnamurthy, L., G. A. Vecchi, R. Msadek, H. Murakami, A. Wittenberg, and F. Zeng, 2016: Impact of strong ENSO on regional tropical cyclone activity in a high-resolution climate model in the North Pacific and North Atlantic. J. Climate, 29, 2375-2394. doi:10.1175/JCLI-D-0468.1

25. Lee, S.-K., A. T. Wittenberg, D. B. Enfield, S. J. Weaver, C. Wang, and R. M. Atlas, 2016: 
U.S. regional tornado outbreaks and their links to spring ENSO phases and North Atlantic SST variability. Environ. Res. Lett., 11 (4), 044008. doi:10.1088/1748-9326/11/4/044008

26. Zheng, X. T., Hui, C., \& Yeh, S. W. (2018). Response of ENSO amplitude to global warming in CESM large ensemble: uncertainty due to internal variability. Climate Dynamics, 50(11-12), 4019-4035.

27. Capotondi, A., Y.-G. Ham, A. T. Wittenberg, and J.-S. Kug, 2015a: Climate model biases and El Niño Southern Oscillation (ENSO) simulation. U.S. CLIVAR Variations, 13 (1), 2125.

28. Guilyardi, E., A. Capotondi, and M. Lengaigne, S. Thual, and A. T. Wittenberg, 2020: ENSO modeling: History, progress, and challenges. Chapter 9 of: El Niño Southern Oscillation in a Changing Climate, American Geophysical Union, Washington, DC, pp. 201-226. doi: $\underline{10.1002 / 9781119548164 . \operatorname{ch} 9}$

29. Guilyardi, E., Wittenberg, A., Fedorov, A., Collins, M., Wang, C., Capotondi, A., ... \& Stockdale, T. (2009). Understanding El Niño in ocean-atmosphere general circulation models: Progress and challenges. Bulletin of the American Meteorological Society, 90(3), 325-340. https://doi.org/10.1175/2008BAMS2387.1

30. Lee, S. K., Lopez, H., Chung, E. S., DiNezio, P., Yeh, S. W., \& Wittenberg, A. T. (2018). On the fragile relationship between El Niño and California rainfall. Geophysical Research Letters, 45(2), 907-915. https://doi.org/10.1002/2017GL076197

31. Chen, C., Cane, M. A., Wittenberg, A. T., \& Chen, D. (2017). ENSO in the CMIP5 simulations: life cycles, diversity, and responses to climate change. Journal of Climate, 30(2), 775-801. https://doi.org/10.1175/JCLI-D-15-0901.1

32. Wittenberg AT (2002) ENSO response to altered climates. Ph.D. thesis, Princeton 
University. 475pp. doi:10.13140/RG.2.1.1777.8403/1

33. Kug, J. S., Choi, J., An, S. I., Jin, F. F., \& Wittenberg, A. T. (2010). Warm pool and cold tongue El Niño events as simulated by the GFDL 2.1 coupled GCM. Journal of Climate, 23(5), 1226-1239. https://doi.org/10.1175/2009JCLI3293.1

34. Moore, A. M., and R. Kleeman, 1999a: The nonnormal nature of El Niño and intraseasonal variability. J. Climate, 12, 2965-2982.

35. Moore, A. M., and R. Kleeman, 1999b: Stochastic forcing of ENSO by the intraseasonal oscillation. J. Climate, 12, 1199-1220.

36. Luther, D. S., D. E. Harrison, and R. A. Knox, 1983: Zonal winds in the central equatorial Pacific and El Niño. Science, 222, 327-330.

37. Harrison, D. E., \& Schopf, P. S. (1984). Kelvin-wave-induced anomalous advection and the onset of surface warming in El Niño events. Monthly weather review, 112(5), 923-933.

38. McPhaden, M. J., 1999: Climate oscillations: Genesis and evolution of the 1997-98 El Niño. Science, 283, 950-954.

39. Vecchi, G. A., \& Harrison, D. E. (2000). Tropical Pacific sea surface temperature anomalies, El Niño, and equatorial westerly wind events. Journal of climate, 13(11), 1814-1830.

40. Eisenman, I., L. Yu, E. Tziperman, 2005: Westerly wind bursts: ENSO's tail rather than the dog? J. Climate, 18, 5224-5238.

41. Perez, C. L., Moore, A. M., Zavala-Garay, J., \& Kleeman, R. (2005). A comparison of the influence of additive and multiplicative stochastic forcing on a coupled model of ENSO. Journal of climate, 18(23), 5066-5085. 
42. Gebbie, G., I. Eisenman, A. Wittenberg, and E. Tziperman, 2007: Modulation of westerly wind burst by sea surface temperature: A semi-stochastic feedback for ENSO. J. Atmos. Sci., 64(9):3281-3295, doi:10.1175/JAS4029.1

43. Jin F-F., L. Lin, A. Timmermann, and J. Zhao, 2007: Ensemble-mean dynamics of the ENSO recharge oscillator under state-dependent stochastic forcing. Geophys. Res. Lett., 34, L03807, doi:10.1029/2006GL027372.

44. Lopez, H., Kirtman, B. P., Tziperman, E., \& Gebbie, G. (2013). Impact of interactive westerly wind bursts on CCSM3. Dynamics of atmospheres and oceans, 59, 24-51.

45. Lopez, H., \& Kirtman, B. P. (2013). Westerly wind bursts and the diversity of ENSO in CCSM3 and CCSM4. Geophysical research letters, 40(17), 4722-4727.

46. Lian, T, Y Tang, L. Zhou, S. U. Islam, C. Zhang, X. Li, and Z. Ling. "Westerly wind bursts simulated in CAM4 and CCSM4." Climate dynamics 50, no. 3-4 (2018): 1353-1371.

47. Choi, K.-Y., G. A. Vecchi, and A. T. Wittenberg, 2013: ENSO transition, duration and amplitude asymmetries: Role of the nonlinear wind stress coupling in a conceptual model. J. Climate, 26, 9462-9476. doi:10.1175/JCLI-D-13-00045.1

48. Choi, K.-Y., G. A. Vecchi, and A. T. Wittenberg, 2015: Nonlinear zonal wind response to ENSO in the CMIP5 models: Roles of the zonal and meridional shift of the ITCZ/SPCZ and the simulated climatological precipitation. J. Climate, 28, 8556-8573. doi:10.1175/JCLI-D$15-0211.1$

49. Trenberth, K. E., Branstator, G. W., Karoly, D., Kumar, A., Lau, N. C., \& Ropelewski, C. (1998). Progress during TOGA in understanding and modeling global teleconnections associated with tropical sea surface temperatures. Journal of Geophysical Research: Oceans, 103(C7), 14291-14324. 
50. Sarachik, E. S., \& Cane, M. A. (2010). The El Nino-southern oscillation phenomenon. Cambridge University Press.

51. Schubert, S. D., Suarez, M. J., Pegion, P. J., Koster, R. D., \& Bacmeister, J. T. (2004). Causes of long-term drought in the US Great Plains. Journal of Climate, 17(3), 485-503.

52. Seager, R., Harnik, N., Robinson, W. A., Kushnir, Y., Ting, M., Huang, H. P., \& Velez, J. (2005). Mechanisms of ENSO-forcing of hemispherically symmetric precipitation variability. Quarterly Journal of the Royal Meteorological Society: A journal of the atmospheric sciences, applied meteorology and physical oceanography, 131(608), 15011527.

53. Herweijer, C., Seager, R., \& Cook, E. R. (2006). North American droughts of the mid to late nineteenth century: a history, simulation and implication for Mediaeval drought. The Holocene, 16(2), 159-171.

54. Yu, J. Y., \& Zou, Y. (2013). The enhanced drying effect of Central-Pacific El Niño on US winter. Environmental Research Letters, 8(1), 014019.

55. Infanti, J. M., \& Kirtman, B. P. (2016). North American rainfall and temperature prediction response to the diversity of ENSO. Climate Dynamics, 46(9-10), 3007-3023.

56. Fasullo, J. T., Otto-Bliesner, B. L., \& Stevenson, S. (2018). ENSO's changing influence on temperature, precipitation, and wildfire in a warming climate. Geophysical Research Letters, 45(17), 9216-9225.

57. Graham, F. S., A. T. Wittenberg, J. N. Brown, S. J. Marsland, and N. J. Holbrook, 2017: Understanding the double peaked El Niño in coupled GCMs. Climate Dyn., 48 (5), 20452063. doi:10.1007/s00382-016-3189-1

58. Ding, H., M. Newman, M. A. Alexander, and A. T. Wittenberg, 2020: Relating CMIP5 
model biases to seasonal forecast skill in the tropical Pacific. Geophys. Res. Lett., 47, (5), e2019GL086765. doi:10.1029/2019GL086765

59. Fedorov, A., S. Hu, A. T. Wittenberg, A. Levine, and C. Deser, 2020: ENSO low-frequency modulations and mean state interactions. Chapter 8 of: El Niño Southern Oscillation in a Changing Climate, American Geophysical Union, Washington, DC, pp. 173-198. doi: $\underline{10.1002 / 9781119548164 . \operatorname{ch} 8}$

60. Ray, S., A. T. Wittenberg, S. M. Griffies, and F. Zeng, 2018: Understanding the equatorial Pacific cold tongue time-mean heat budget, Part I: Diagnostic framework. J. Climate, 31 (24), 9965-9985. doi:10.1175/JCLI-D-18-0152.1

61. Ray, S., A. T. Wittenberg, S. M. Griffies, and F. Zeng, 2018: Understanding the equatorial Pacific cold tongue time-mean heat budget, Part II: Evaluation of the GFDL-FLOR coupled GCM. J. Climate, 31 (24), 9987-10011. doi:10.1175/JCLI-D-18-0153.1

62. Kim, D., J.-S. Kug, I.-S. Kang, F.-F. Jin, and A. T. Wittenberg, 2008: Tropical Pacific impacts of convective momentum transport in the SNU coupled GCM. Climate Dyn., 31, 213-226. doi:10.1007/s00382-007-0348-4

63. Planton, Y., E. Guilyardi, A. T. Wittenberg, J. Lee, P. J. Gleckler, T. Bayr, S. McGregor, M. J. McPhaden, S. Power, R. Roehrig, J. Vialard, and A. Voldoire: Evaluating climate models with the CLIVAR 2020 ENSO metrics package. Bull. Amer. Meteorol. Soc., in press. doi:10.1175/BAMS-D-19-0337.1

64. Stevenson, S., Wittenberg, A. T., Fasullo, J., Coats, S., \& Otto-Bliesner, B. (2020). Understanding Diverse Model Projections of Future Extreme El Niño. Journal of Climate, 149. Doi:10.1175/JCLI-D-19-0969.1. 
65. Huang, B., Thorne, P. W., Banzon, V. F., Boyer, T., Chepurin, G., Lawrimore, J. H., ... \& Zhang, H. M. (2017). Extended reconstructed sea surface temperature, version 5 (ERSSTv5): upgrades, validations, and intercomparisons. Journal of Climate, 30(20), 8179-8205.

66. Adler, R. F., Huffman, G. J., Chang, A., Ferraro, R., Xie, P. P., Janowiak, J., ... \& Gruber, A. (2003). The version-2 global precipitation climatology project (GPCP) monthly precipitation analysis (1979-present). Journal of hydrometeorology, 4(6), 1147-1167.

67. Kay, J. Deser, C. Phillips, A. Mai, A. Hannay, C. Strand, G. Arblaster, The Community Earth System Model (CESM) Large Ensemble Project: A community resource for studying climate change in the presence of internal climate variability. Bull. Am. Meteorol. Soc. 96, 13331349 (2015).

68. Meinhausen, M. \& Coauthors. The RCP greenhouse gas concentration and their extension from 1765 to 2300. Clim. Change 109, 213, doi:10.1007/s10584-011-0156-z (2011).

69. Lamarque, J. F. \& Coauthors. Global and regional evolution of short-lived radiatively-active gases and aerosols in the Representative Concentration Pathways. Clim. Change., 109, 191$212(2011)$

70. Predybaylo, E., Stenchikov, G. L., Wittenberg, A. T., \& Zeng, F. (2017). Impacts of a Pinatubo-size volcanic eruption on ENSO. Journal of Geophysical Research: Atmospheres, 122(2), 925-947. https://doi.org/10.1002/2016JD025796

71. Predybaylo, E., G. Stenchikov, A. T. Wittenberg, and S. Osipov, 2020: El Niño / Southern Oscillation response to low-latitude volcanic eruptions depends on ocean pre-conditions and eruption timing. Nat. Commun. Earth Environ., 1, 12. doi:10.1038/s43247-020-0013-y

72. Gebbie, G., \& Tziperman, E. (2009). Predictability of SST-modulated westerly wind bursts. Journal of climate, 22(14), 3894-3909. 
73. Lopez, H. and and B. P. Kirtman, 2018: ENSO influence over the Pacific North American sector: Uncertainty due to atmospheric internal variability. Clim. Dyn., 1-24, doi:10.1007/s00382-018-4500-0.

74. Zhang, C., \& Gottschalck, J. (2002). SST anomalies of ENSO and the Madden-Julian oscillation in the equatorial Pacific. Journal of Climate, 15(17), 2429-2445.

\section{Figure Captions:}

Figure 1. Spatio-temporal evolution of El Niño events. Composite of (top) monthly sea surface temperature anomalies [SSTAs, ${ }^{\circ} \mathrm{C}$ ] for El Niño events for a) observed, b) the $20 \mathrm{C}$ (i.e., $1951-2000$ period), c) $21 \mathrm{C}$ (i.e., $2051-2100$ period), and d) the $21^{\text {st }}$ minus $20^{\text {th }}$ Century difference. Similarly, e), f), g), and h) show the composite of monthly precipitation anomalies [mm/day]. Abscissa represents longitude across the Pacific Ocean, and ordinate represents time from January of the onset year (Year 0) to December of the decay year (Year 1). The composite is meridionally averaged from $5^{\circ} \mathrm{S}$ to $5^{\circ} \mathrm{N}$. Hatching on panels d) and h) indicates statistical significance at the $95 \%$ confidence level using a Student's t-test.

Figure 2. Mixed layer heat budget analysis during El Niño events. The top row shows the composites for the heating tendency, thermocline feedback, zonal advective feedback, Ekman feedback, and residual term from Eq. 1 (color, $\mathrm{Wm}^{2}$ ) and heat content anomaly (green contour, $10^{8} \mathrm{Jm}^{-2}$ ) for the $20^{\text {th }}$ Century (20C) and the bottom row shows the difference between the $21^{\text {st }}$ minus the $20^{\text {th }}$ Century (21C). All terms are quantified based on the assumption of a $75-m$ mixed layer depth.

Figure 3. Projected changes in the Pacific mean state. Two-year repeated monthly climatology of a) sea surface temperature $\left[{ }^{\circ} \mathrm{C}\right]$, b) thermocline depth $[\mathrm{m}]$, and c) precipitation 
$\left[\mathrm{mm} /\right.$ day] meridionally averaged from $5^{\circ} \mathrm{S}-5^{\circ} \mathrm{N}$ along the Pacific Ocean for the 1951-2000 period. Panels d), e), and f) show the difference between the 2051-2100 minus the 1951-2000 period mean climatology. The monthly climatology is computed from the ensemble mean of all 30 ensemble members. Hatching indicates where the differences are statistically significant at the $95^{\text {th }}$ percentile based on a Student's T-test. g) A randomly chosen snapshot illustrating the relationship between WWBs [contour, $\mathrm{Nm}^{-2}$ ] and downwelling Kelvin wave [color shading, $\mathrm{Nm}^{-}$ ${ }^{1}$ ] as defined by Eq. 2. h) Daily climatology of the downwelling Kelvin wave forcing for the $20^{\text {th }}$ (blue) and $21^{\text {st }}$ (red) Century. The thick lines represent the ensemble mean, while the shading corresponds to the ensemble spread defined by the full min-max inter-ensemble range.

Figure 4. Projected changes in the remote impacts of EI Niño. a) December-January-February (DJF) global composite anomalies of $200 \mathrm{hPa}$ streamfunction (contour, interval $10^{6} \mathrm{~s}^{-1}$ ) and $200 \mathrm{hPa}$ velocity potential (color, $10^{6} \mathrm{~s}^{-1}$ ) during late $20^{\text {th }}$ Century El Niño events. Also shown are the regional impacts on 2-meter reference temperature $(\mathrm{K})$ and precipitation $(\mathrm{mm} /$ day) for North America, South America, and Australia. b) shows the differences between 21C minus 20C composites. Negative streamfunction (velocity potential) indicates counter-clockwise (divergent) upper-level flow. Contour interval is $4 \times 10^{5} \mathrm{~s}^{-1}\left(10^{5} \mathrm{~s}^{-1}\right)$ for the streamfunction (velocity potential). 
Figures
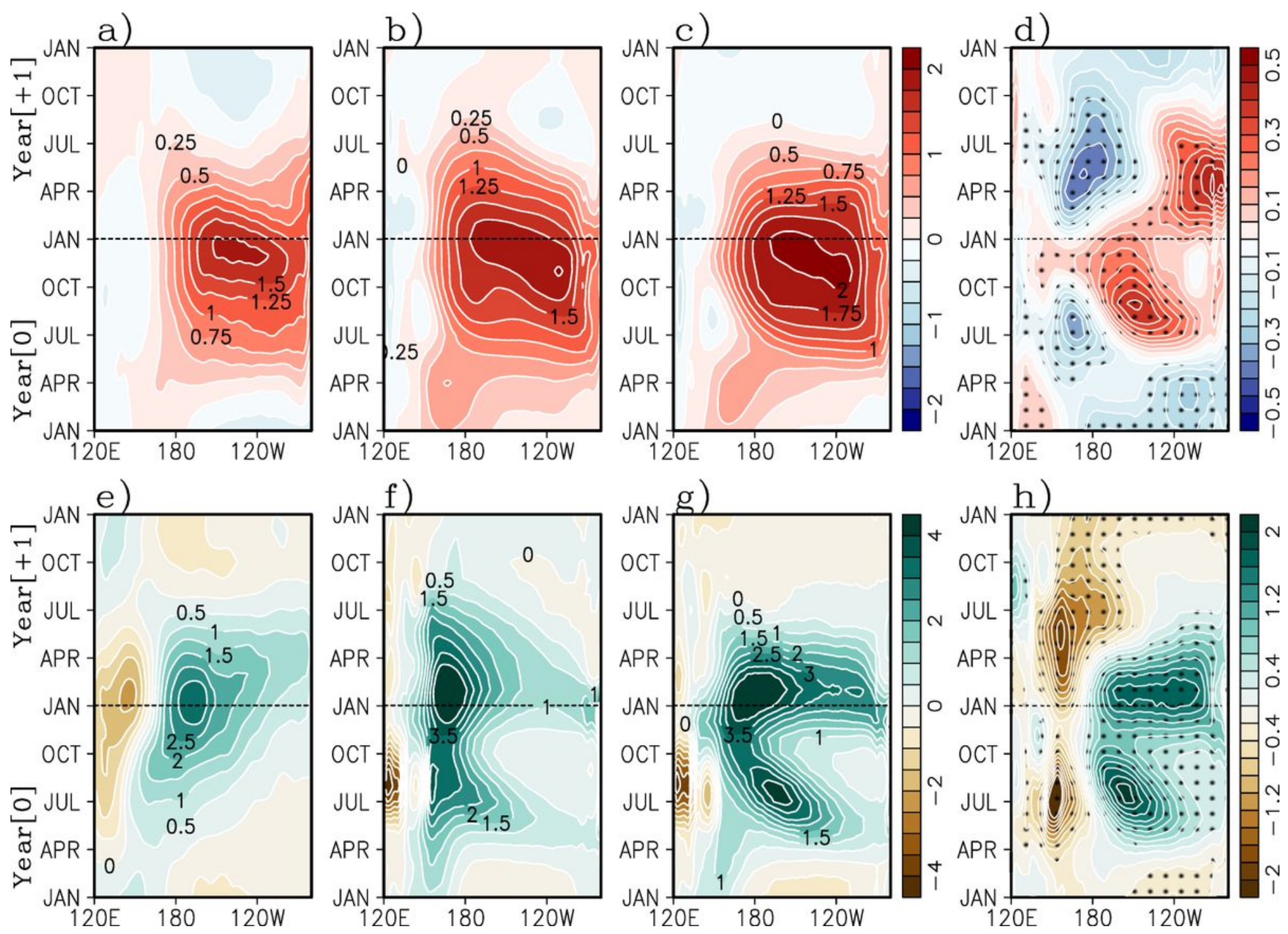

\section{Figure 1}

Spatio-temporal evolution of El Niño events. Composite of (top) monthly sea surface temperature anomalies [SSTAs, ${ }^{\circ} \mathrm{C}$ ] for El Niño events for a) observed, b) the $20 \mathrm{C}$ (i.e., 1951-2000 period), c) 21C (i.e., 2051-2100 period), and d) the 21st minus 20th Century difference. Similarly, e), f), g), and h) show the composite of monthly precipitation anomalies [mm/day]. Abscissa represents longitude across the Pacific Ocean, and ordinate represents time from January of the onset year (Year 0) to December of the decay year (Year 1). The composite is meridionally averaged from $5^{\circ} \mathrm{S}$ to $5^{\circ} \mathrm{N}$. Hatching on panels $\mathrm{d}$ ) and h) indicates statistical significance at the $95 \%$ confidence level using a Student's t-test. 

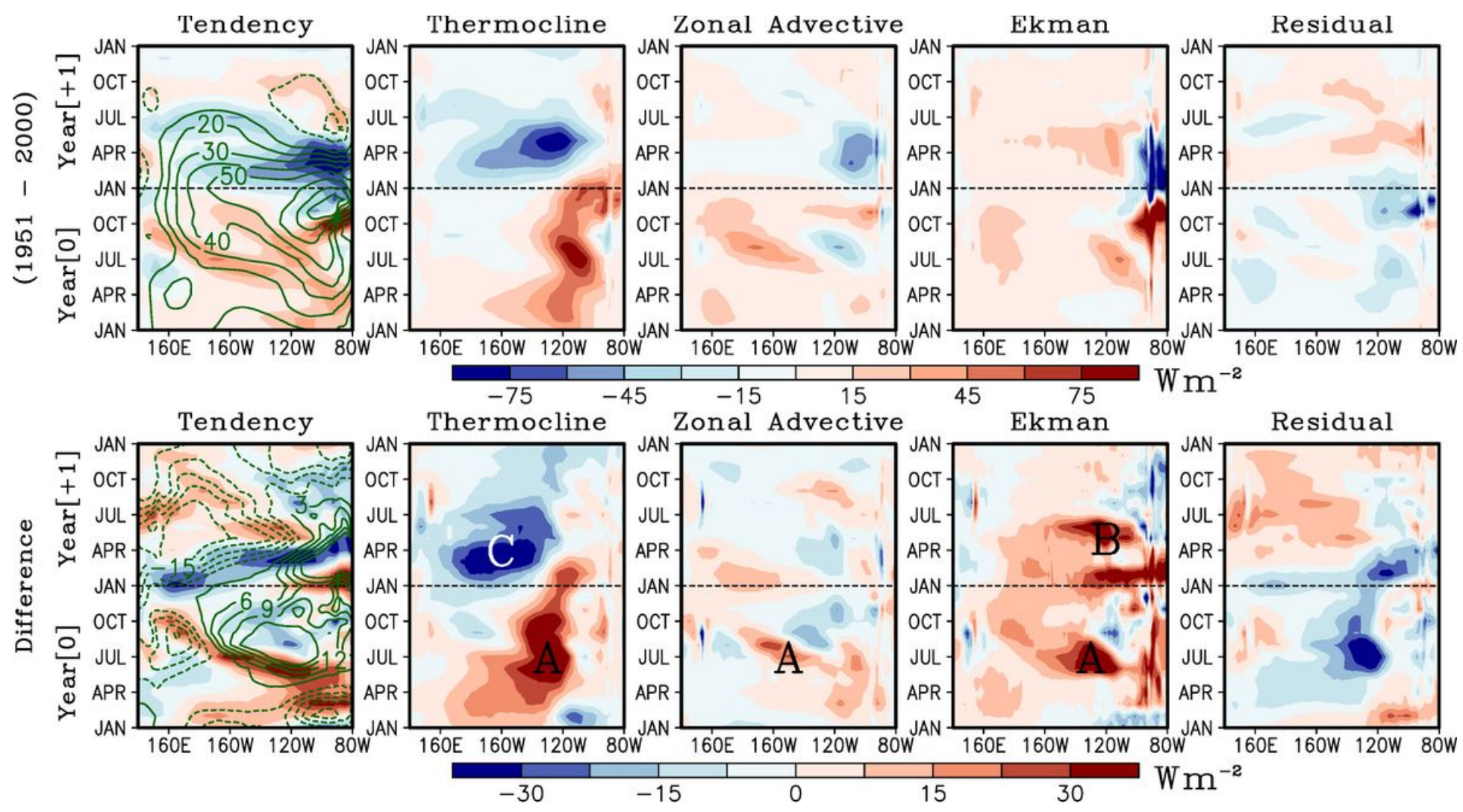

Figure 2

Mixed layer heat budget analysis during El Niño events. The top row shows the composites for the heating tendency, thermocline feedback, zonal advective feedback, Ekman feedback, and residual term from Eq. 1 (color, Wm2) and heat content anomaly (green contour, $108 \mathrm{Jm}-2$ ) for the 20th Century (20C) and the bottom row shows the difference between the 21 st minus the 20th Century (21C). All terms are quantified based on the assumption of a 75-m mixed layer depth. 
a)
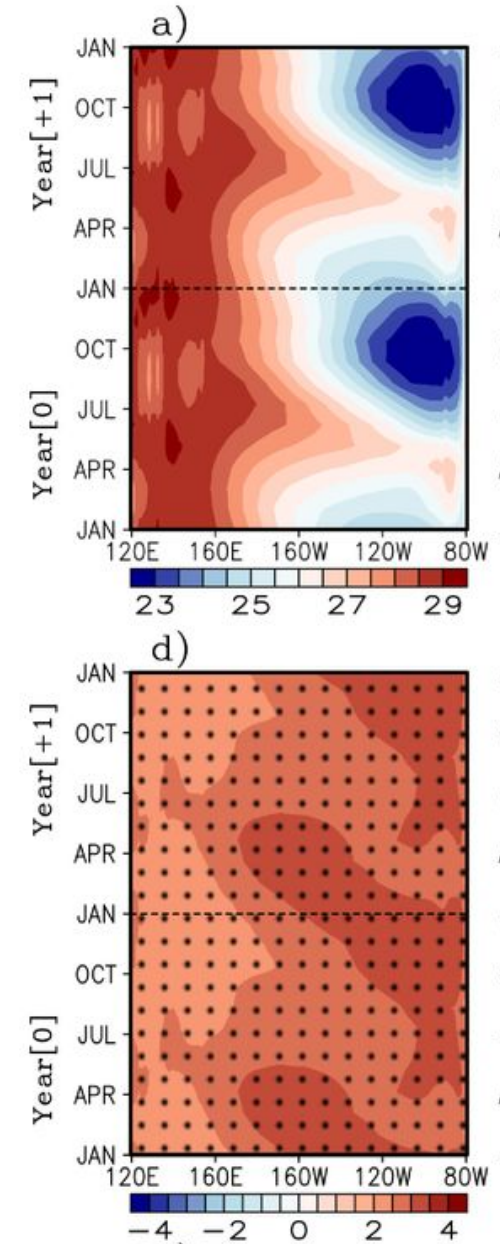

g) b)

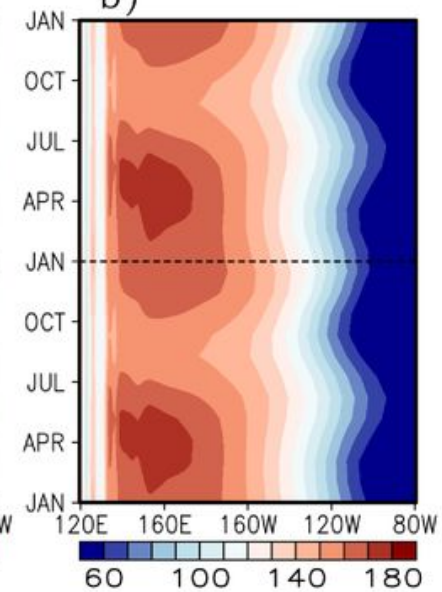

e)

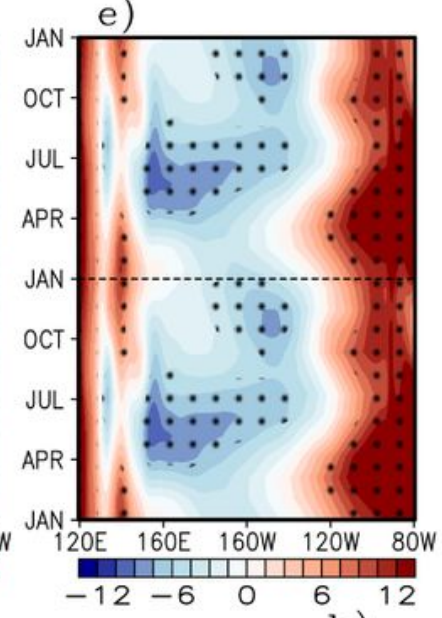

c)
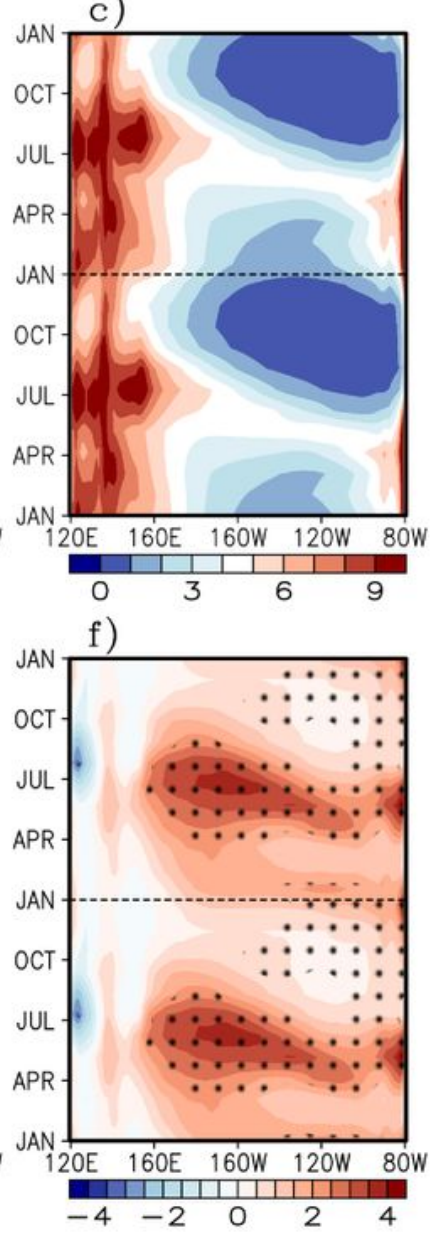

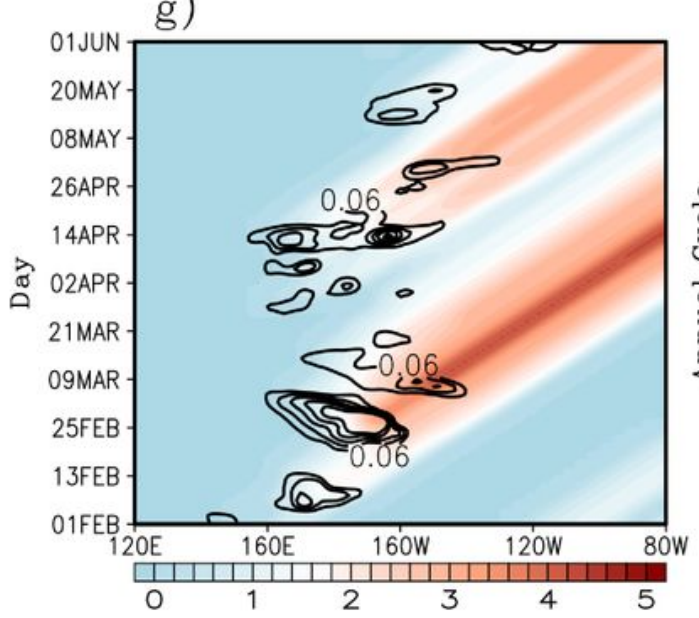

h)

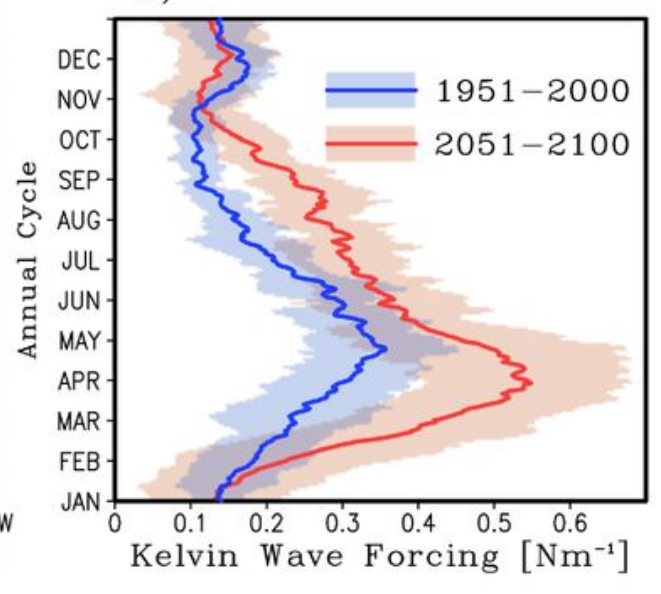

\section{Figure 3}

Projected changes in the Pacific mean state. Two-year repeated monthly climatology of a) sea surface temperature $\left.\left[{ }^{\circ} \mathrm{C}\right], \mathrm{b}\right)$ thermocline depth $[\mathrm{m}]$, and c) precipitation $\left[\mathrm{mm} /\right.$ day] meridionally averaged from $5^{\circ} \mathrm{S}-$ $5^{\circ} \mathrm{N}$ along the Pacific Ocean for the 1951-2000 period. Panels d), e), and f) show the difference between the 2051-2100 minus the 1951-2000 period mean climatology. The monthly climatology is computed from the ensemble mean of all 30 ensemble members. Hatching indicates where the differences are 
statistically significant at the 95th percentile based on a Student's T-test. g) A randomly chosen snapshot illustrating the relationship between WWBs [contour, Nm-2] and downwelling Kelvin wave [color shading, $\mathrm{Nm}-1$ ] as defined by Eq. 2. h) Daily climatology of the downwelling Kelvin wave forcing for the 20th (blue) and 21 st (red) Century. The thick lines represent the ensemble mean, while the shading corresponds to the ensemble spread defined by the full min-max inter-ensemble range.

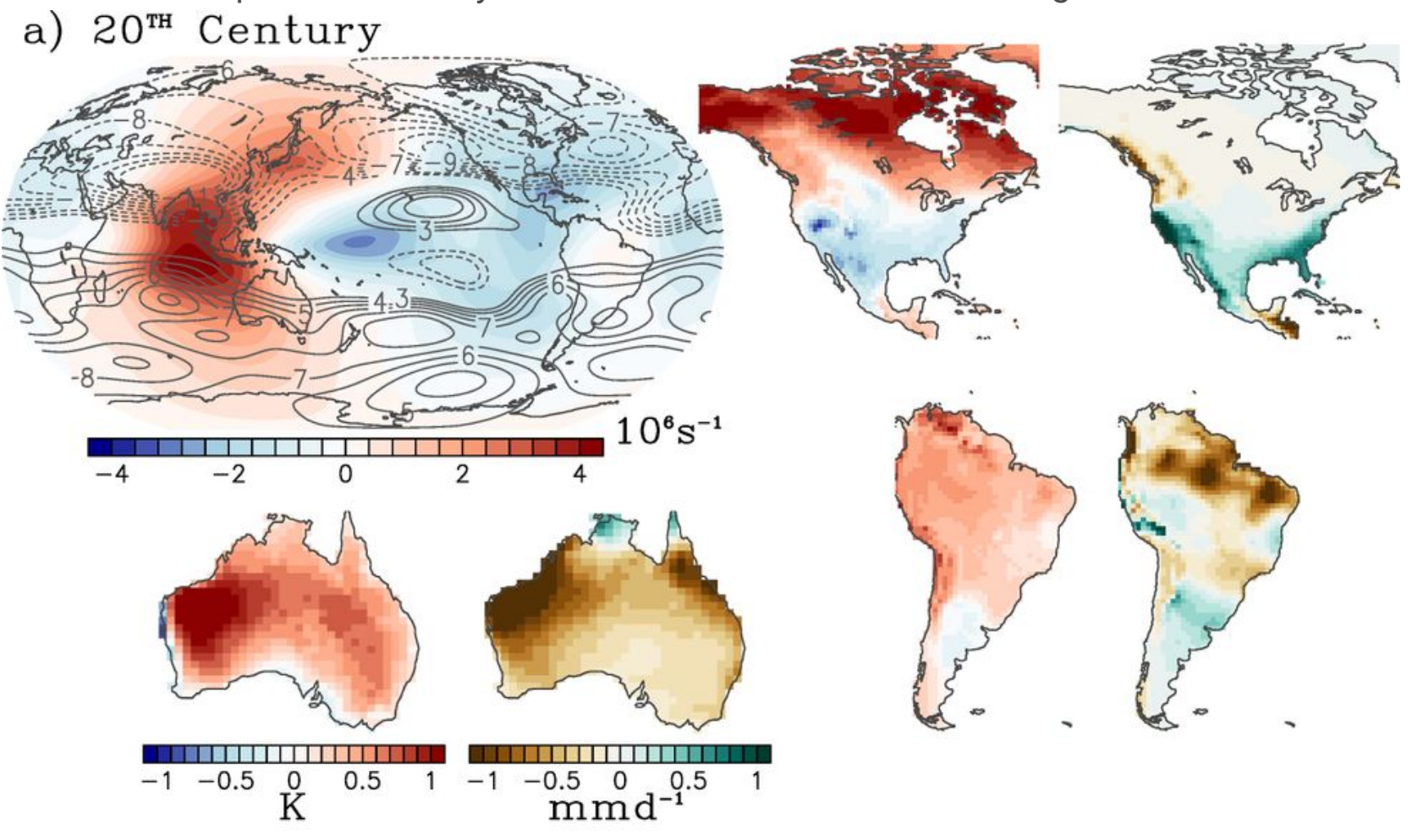

b) Difference

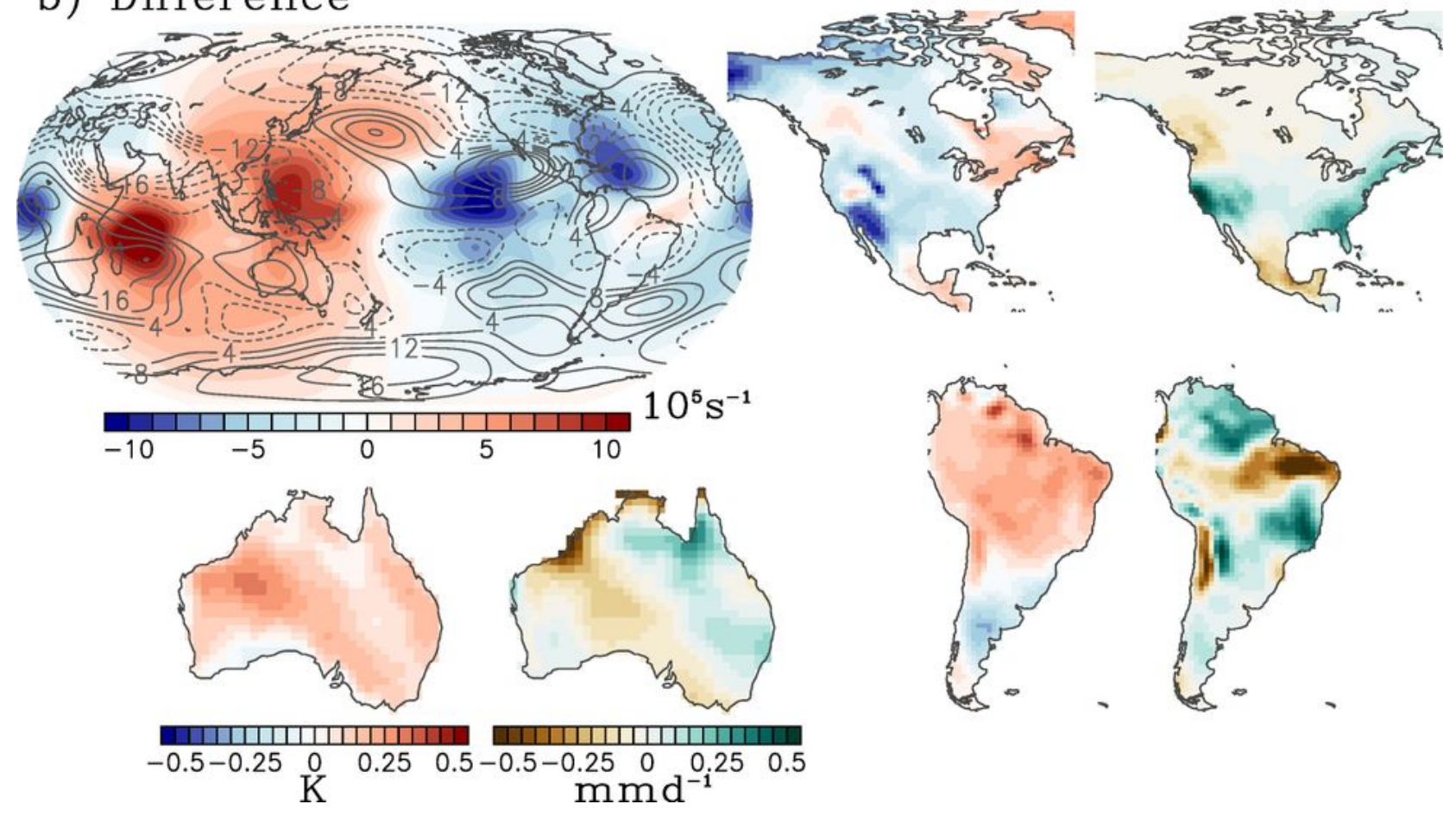

Figure 4 
Projected changes in the remote impacts of El Niño. a) December-January-February (DJF) global composite anomalies of $200 \mathrm{hPa}$ streamfunction (contour, interval $106 \mathrm{~s}-1$ ) and $200 \mathrm{hPa}$ velocity potential (color, $106 \mathrm{~s}-1$ ) during late 20th Century El Niño events. Also shown are the regional impacts on 2-meter reference temperature $(\mathrm{K})$ and precipitation $(\mathrm{mm} /$ day) for North America, South America, and Australia. b) shows the differences between $21 \mathrm{C}$ minus $20 \mathrm{C}$ composites. Negative streamfunction (velocity potential) indicates counter-clockwise (divergent) upper-level flow. Contour interval is $4 \times 105$ s-1 (105 s-1) for the streamfunction (velocity potential).

\section{Supplementary Files}

This is a list of supplementary files associated with this preprint. Click to download.

- ENSOfutureSuppInfoNCC.docx 